SILVA, Cesar Agenor Fernandes da. Representações, vulgarização e imagética científicas na imprensa da corte fluminense do século XIX. Domínios da Imagem, Londrina, v. 10, n. 19, p. 40-75, jul./dez. 2016.

ISSN 2237-9126

Recebido em 3/11/2016 e aprovado em 20/12/2016

\title{
REPRESENTAÇÕES, VULGARIZAÇÃO E IMAGÉTICA CIENTÍFICAS NA IMPRENSA DA CORTE FLUMINENSE DO SÉCULO XIX
}

\section{REPRESENTATIONS, POPULARIZATION AND SCIENTIFIC IMAGERY IN THE RIO DE JANEIRO PRESS COURT OF THE 19TH CENTURY}

Cesar Agenor Fernandes da Silva'

\section{Resumo}

O presente trabalho tem por objetivo compreender as nuances e os contornos da vulgarização científica e seu papel no projeto civilizatório para o Brasil veiculado pela imprensa periódica, produzida no Rio de Janeiro na primeira metade do século XIX.As revistas da época foramferramentas importantes destas ações com objetivos civilizatórios, que anunciavam, quase sem exceções, em suas introduções, que seu objetivo era o de levar e espalhar as luzes entre os homens livres do país.Essas publicações foram importantes na formulação de um discurso acerca do Brasil, do brasileiro e de sua literatura que gradativamente foi sendo absorvido pela sociedade.

Palavras-chave: Vulgarização da ciência. História da imprensa. Rio de Janeiro oitocentista.

\begin{abstract}
This work aims to understand the nuances and the contours of the science popularization and its role in the project of civilization for Brazil aired by the periodical press, produced in Rio de Janeiro in the first half of the 19th century. The magazinesof the time wereimportant tools of these actions with goals of civilization, which advertised, almost without exception, in their introductions, its aim was to lead and spread the lights among the freemen of the country. These publications were important in the formulation of a speech about Brazil, of the Brazilian and Brazilian literature gradually was being absorbed by society.
\end{abstract}

Keywords: Science popularization. History of the press. 19th century's Rio de Janeiro.

1 Doutor em História e Cultura Social pela Universidade Estadual Paulista UNESP. Atua como docente-pesquisador no ensino superior desde 2004, em instituições públicas e privadas. Suas pesquisas de mestrado e doutorado tomaram como questão central o papel do conhecimento técnico-científico no projeto civilizatório dos homens de letras do Brasil no século XIX e os meios nos quais esses conhecimentos foram vulgarizados, a imprensa periódica. É professor na Universidade Católica de Santos desde 2010, na qual atua como membro do Comitê Institucional de Iniciação Científica e coordena o Programa de Iniciação Científica para o Ensino Médio. 
SILVA, Cesar Agenor Fernandes da. Representações, vulgarização e imagética científicas na imprensa da corte fluminense do século XIX. Domínios da Imagem, Londrina, v. 10, n. 19, p. 40-75, jul./dez. 2016.

ISSN 2237-9126

Podemos afirmar, sem muito receito de cometer um erro crasso, que o século XXI consolidou a chamada era da informação e, especialmente, da imagem. Com nossos dispositivos portáteis conseguimos visualizar em poucos segundos uma plêiade de imagens. Podemos acessar desde as fotografias do espaço profundo produzidas pelos telescópios orbitais ou até mesmo conhecer espécies animais muito diferentes da fauna de nossas localidades.

As crianças que têm a possibilidade de acesso às tecnologias de comunicação coetânea já incorporam em seu cotidiano a possibilidade de acesso às imagens e representações variadas. Caso surja a curiosidade de saber como é a aparência de um Diceros bicornis (nome científico dos rinocerontes-negros), basta digitar ou falar o nome do espécime em um dos sites de mecanismo de busca de conteúdo na internet e depois dar um toque na palavra imagens que mais de mil resultados estarão disponíveis.

Esta facilidade de acesso à informação pictográfica, ou utilizando um neologismo à informação pixelgráfica, ${ }^{2}$ nos traz uma sensação de familiaridade com as imagens que são poucas as ocasiões que paramos para refletir sobre os possíveis impactos que uma imagem pode causar em públicos pouco acostumados a este tipo de representação.

O historiador francês Michel Volvelle há mais de 20 anos, no livro Imagens e Imaginário na História (1991), deixou clara a importância e o impacto das imagens nas populações europeias, especialmente a francesa, desde a Idade Média até o século XX. Volvelle (1991, p.151-

2 De acordo com definição do dicionário HOUAISS, a palavra pixel significa "ponto luminoso do monitor de vídeo que, juntamente com outros, forma as imagens na tela; ponto". Grande Dicionário Houaiss da Língua Portuguesa. [Online]. Disponível em: <https://houaiss.vol.com.br> 
SILVA, Cesar Agenor Fernandes da. Representações, vulgarização e imagética científicas na imprensa da corte fluminense do século XIX. Domínios da Imagem, Londrina, v. 10, n. 19, p. 40-75, jul./dez. 2016.

ISSN 2237-9126

180) nos contou, por exemplo, uma história da revolução francesa a partir das imagens, ou melhor, como os coetâneos à revolução compuseram as representações acerca do processo histórico que vivenciavam. Neste trabalho ele nos revela que as imagens construídas, consumidas e reproduzidas acerca da situação social, especialmente as caricaturas ou gravuras de imprensa, foram importantes armas políticas antes, durante e depois do processo revolucionário. Elas contribuíram para construir representações que, por sua vez, compuseram instrumentos de subjetivação.

Se nos dias de hoje o acesso a imagem se dá de forma simples, cotidiana e com alto grau de naturalidade, desde meados do século $X V \|^{3}$ até $O$ início do século $X X$, a grande fonte de reprodução e consumo de imagens era a imprensa periódica. Foram os periodistas e os tipógrafos os responsáveis por vulgarizar a imagem, com os mais variados objetivos. Na Europa, desde o século XVII, e na América, com maior vigor a partir do início do século XIX, a imprensa periódica proliferou. As temáticas abordadas por essa estirpe de publicação era variada, iam desde as que se dedicavam predominantemente as temáticas políticas passando por revistas literárias e científicas chegando a publicações dedicadas à moda. ${ }^{4}$ No Brasil, do século XIX, o fenômeno não foi diferente. Os habitantes do país, especialmente do Rio de Janeiro, passaram a tomar contato com representações sobre a fauna e a flora, a arquitetura, ageografia, e costumes de populações de outras localidades por meio da imprensa periódica. Para os periodistas, das primeiras décadas do século XIX, ligados de alguma

\footnotetext{
${ }^{3}$ No período de Luis XIV, por exemplo, magazines como "La Mercure Gallant" reproduziam gravuras dos trajes da corte ou cenas do cotidiano da nobreza que deveriam servir de exemplo de sofisticação e superiodidade.

4 Sobre este último tipo de publicação e sua influência na formação da chamada cultura do consumo consulte (BURKE, 2008).
} 
SILVA, Cesar Agenor Fernandes da. Representações, vulgarização e imagética científicas na imprensa da corte fluminense do século XIX. Domínios da Imagem, Londrina, v. 10, n. 19, p. 40-75, jul./dez. 2016.

ISSN 2237-9126

forma ao Brasil, escrever, publicar e divulgar seus periódicos era mais do que um simples exercício intelectual e de vaidade, pois estes homens acreditavam que estavam cumprindo uma missão, a de espalhar as luzes da razão e da ciência para o restante da população - que necessitava se civilizar e abraçar as boas novas do novo século.

A propósito dos conhecimentos e valores científicos, tornou-se corriqueiro, nas páginas dessas revistas literárias, a veiculação de artigos que tratavam de avanços técnico-científicos, entendidos em um sentido bastante amplo: novas invenções, registros de novas patentes, observações astronômicas recém-divulgadas, métodos de aprendizagem há pouco descobertos, progressos nas áreas da medicina, das ciências sociais, da arquitetura e da engenharia, inovações do maquinário da indústria, aperfeiçoamentos de instrumentos musicais, etc.

A questão que discutiremos nesse artigo gira exatamente em torno de tais avanços e as imagens associadas a essa veiculação por meio das publicações periódicas do Rio de Janeiro nas primeiras décadas do século XIX. Ao realizarmos esse movimento, o que pretendemos é descrever como o conhecimento técnico-científico e, sobretudo, o uso público da razão5 tiveram papel fundamental no

5 Tomamos aqui por referência as discussões realizadas por Roger Chartier (2009, p.49-72) e por Márcia Regina C. Naxara (2004, p.41-80). Ambos discutem a questão do uso púbico da razão apregoado por Kant, porém, Chartier também volta seu olhar à cultura política do Antigo Regime e Naxara amplia a perspectiva kantiana ao analisar as formas de representação do mundo e da natureza produzidas pela ilustração na passagem do século XVIII para o XIX, e que se estendeu por todo o oitocentos. Nesta perspectiva, é necessário deixarmos claro que os homens de letras brasileiros que viam em si a missão de civilizar o Brasil, apregoavam, sem exceção, que o uso da razão deveria ser uma ferramenta para todos os elementos da vida. Tal concepção abarcava a condução da coisa e da vida pública, bem como a necessidade de se conhecer o mundo natural para poder tornar-se senhor dele e, com isso, imprimir na nação nascente técnicas e saberes racionais e eficientes em todos os ramos da produção, especialmente o rural. 
SILVA, Cesar Agenor Fernandes da. Representações, vulgarização e imagética científicas na imprensa da corte fluminense do século XIX. Domínios da Imagem, Londrina, v. 10, n. 19, p. 40-75, jul./dez. 2016.

ISSN 2237-9126

projeto de civilização dos homens de letras que viviam no Brasil. Tal projeto, em um primeiro momento, queria elevar o Império LusoBrasileiro e colocá-lo ao lado das poderosas nações do período (Inglaterra e França) e, posteriormente, foi redirecionado para traçar um rumo que a jovem nação brasileira deveria trilhar.

\section{A Imprensa Literária e Científica do Rio de Janeiro}

Tal como a imprensa periódica que despontava no Velho Mundo nas últimas décadas do século XVIII, ocupando o papel de um importante agente educativo (PALLARES-BURKE, 1995), esse gênero de publicação teve um espaço privilegiado no Brasil oitocentista. Embora inicialmente tenham sofrido bastante com a ação da censura do governo português, os magazines tiveram um papel fundamental na formação da cultura escrita brasileira e no debate público que ocorreu na formação do Estado e, posteriormente, na configuração do que poderíamos chamar de "identidade nacional", que se efetivaria no decorrer do século XIX.

Ocorreu uma explosão de publicações periódicas no Brasil oitocentista em várias províncias, ${ }^{\circ}$ sobretudo após 1821, quando a censura foi revogada. No Rio de Janeiro, esse tipo de escrito proliferou. Estima-se que, entre 1821 e 1850, tenham sido editados cerca de 60 títulos na cidade. Em alguns momentos mais pontuais, como nos anos que antecederam a Independência e o início dos anos 30, com a abdicação de Pedro 17, uma enorme gama de publicações periódicas e de panfletos vieram a público. No século XIX, a maior parte desses

\footnotetext{
6 Ver a este respeito o CATALOGO DE PERIÓDICOS MICROFILMADOS, que está organizado por estados e CENTENÁRIO da imprensa no Brasil. RIHGB, 2.V., 1908 (edição especial). Parte I - Gênese e Programa da Imprensa periódica brasileira. Parte II - Annaes da imprensa periódica no Brazil.

7 Ver o trabalho de (LUSTOSA, 2000). Sobre a imprensa no ano da abdicação e nos anos subseqüentes ver esses estudos (BASILE, 2006; SILVA, 2006).
} 
SILVA, Cesar Agenor Fernandes da. Representações, vulgarização e imagética científicas na imprensa da corte fluminense do século XIX. Domínios da Imagem, Londrina, v. 10, n. 19, p. 40-75, jul./dez. 2016.

ISSN 2237-9126

periódicos tratava de temas políticos, no sentido restrito da palavra. Eles lidaram com as questões diárias da governança e deram importante contribuição para a formação de uma "opinião pública", ao apresentarem a seu público conceitos como o de povo, "populaça" e governo.8

As então cultuadas publicações cariocas podem ser divididas em dois tipos: o primeiro, muito comum e abundante, foram os jornais, que tratavam do cotidiano político do Império. ${ }^{9}$ O segundo tipo esquivou-se deliberadamente da política, dedicando-se à difusão da literatura e do conhecimento técnico-científico. Essas publicações veicularam textos de natureza variada, como contos, poesias, memórias, biografias, narrativas de viagem, ensaios científicos, estudos de matemática, entre outros. Inspiradas nas revistas literárias europeias, as publicações nacionais empenharam-se em difundir as letras entre os brasileiros e lançar o embrião de uma cultura científica no país. O recorte desse artigo incide sobre essa formação embrionária.

No final do século XVIII, na Europa, os jornais assumiram o papel

\footnotetext{
8 O historiador Marcello Basile aponta as três principais tendências dos debates promovidos pela imprensa brasileira nos anos 30 do século XIX. Os jornais se dividiam entre os que seguiam as tendências liberais, tanto a moderada quanto a exaltada, e a postura conservadora dos caramurus. (BASILE, 2006, p.61-ss).

9 Sobre a ligação entre imprensa e cotidiano político do Brasil no século XIX um dos estudos mais importantes foi produzidos por Isabel Lustosa (2000). A historiadora descreve o fervoroso e tenso debate promovido pelas folhas públicas no Brasil entre 1821 e 1823. O debate promovido pelos letrados girava em torno da condição política do país e dos projetos de Estado distintos. A abordagem da autora centrou-se na prática jornalística e, ao fazer isso, Lustosa diluiu as personagens e realçou, sobretudo, a contenda e o momento de definição da forma de Estado adotada no Brasil durante a Independência, bem como o papel primordial assumido pelas folhas públicas nesse processo. Outros trabalhos que centram seus esforços no estudo imprensa política estão presentes na coletânea organizada por Marco Morel e Tânia Maraia Bressone "História e Imprensa no Brasil" (2006). Nesse livro problematiza-se a difusão de ideais liberais, e o surgimento dos periódicos em diversas localidades e momentos da história do país. Também aborda-se a contribuição da imprensa para formação de uma opinião pública.
} 
SILVA, Cesar Agenor Fernandes da. Representações, vulgarização e imagética científicas na imprensa da corte fluminense do século XIX. Domínios da Imagem, Londrina, v. 10, n. 19, p. 40-75, jul./dez. 2016.

ISSN 2237-9126

de propagadores das luzes e passaram a "constituir-se num poderoso instrumento do projeto iluminista de mudar as ideias e maneiras das pessoas comuns" (PALLARES-BURKE, 1998, p. 145).10 No país, bem como por toda a América espanhola (PALLARES-BURKE, 1998), essa função também foi ocupada pelas folhas públicas. Não se trata, porém, de uma imitação ou reflexo do que ocorria na Europa, mas sim da incorporação de um princípio que valorizava a palavra escrita e as possibilidades de transformações que as luzes poderiam proporcionar a seus semelhantes; por isso, no Brasil, a imprensa periódica - um suporte dinâmico e que deveria estar preferencialmente livre de censuras -, foi tomada como uma das principais ferramentas na ação dos homens de letras.

A exaltação do papel da imprensa e de sua liberdade foi nota comum entre todos os jornalistas. Foram vários os jornais que destacaram o mesmo ponto ao longo do período, como O Beija-Flor (1830), A Miscelância Scientífica (1835), O Globo (1844), entre outros. O indicador da utilidade pública expôs sua análise sobre a situação da imprensa periódica no Brasil nos termos seguintes

A Imprensa, a mais importante das descobertas, que tem feito os homens, que marcou uma época de contínuo movimento para o aperfeiçoamento do espírito humano, que por sua natureza imortal e independente na sua duração até das revoluções, que abalam, e destroem os fundamentos dos Impérios; e que pela transcendência de sua ação, e efeitos parece o resultado de uma inspiração da Divindade, para dissipar a ignorância, difundir a ilustração por todos os pontos da Terra, retirar os povos da barbárie, da miséria, dos crimes, e dos vícios, que os degradavam; fazer lhes conhecer os seus direitos, e interesses; e elevá-los aquele grau de aperfeiçoamento moral, e social, de que são susceptíveis as faculdades humanas, este invento maravilhoso, a cuja existência

10 Sobre a imprensa periódica Pallares-Burke tem outros textos publicados como, por exemplo, (PALLARES-BURKE, 1995). 
SILVA, Cesar Agenor Fernandes da. Representações, vulgarização e imagética científicas na imprensa da corte fluminense do século XIX. Domínios da Imagem, Londrina, v. 10, n. 19, p. 40-75, jul./dez. 2016.

ISSN 2237-9126

estão ligados os progressos das artes, e das ciências, e dos destinos do gênero humano, tem contudo no Brasil servido, na mão das facções, quase unicamente de instrumento de insultos, de calúnias, e de desmoralização; e como meio de difundir por todas as classes da sociedade 0 hábito da abnegação de todos os sentimentos nobres, e o desprezo para a Autoridade Pública, e para todos os direitos gerais, e individuais; de satisfazer sórdidas ambições, ódios rancorosos, e vinganças abjetas; de estabelecer em princípio a anarquia, e de relaxar, e dissolver todos os vínculos da Associação.

[...]

os periódicos publicados desde a Independência do Império, ou seja nos diferentes períodos do Governo de Pedro I, ou nos que Ihe sucederam, desde a abdicação, com limitadas exceções, tem todos aberrado mais ou menos do sublime, e divino fim da arte de escrever, e da faculdade da publicação dos pensamentos; todos mais ou menos se tem apartado da linha de conduta e do intuito, a que deve tender o público escritos - a ilustração dos homens, e especialmente dos seus Compatriotas; a divulgação das verdades úteis sobre tudo na ordem dos direitos, dos deveres, e das necessidades, e conveniências sociais;

[...]

Fora do Império os efeitos de um semelhante aviltamento, e abuso da imprensa periódica, tem sido a opinião generalizada, de que nos achamos no maior atraso moral, e político, e no mais alto grau de desmoralização, e falta de todos os elementos de organização, e existência social; e com esta opinião a da falta de segurança individual, e garantias a indústria estrangeira, e o desvio de grande número de inteligências, de capitais, de braços, e de recursos de todo o gênero, que deviam afluir ao nosso solo, e concorrer para o rápido desenvolvimento da sua opulência, e grandeza colossal. (O INDICADOR DA UTILIDADE PÚBLICA, 1836, p. 1-2)

Outras marcas desse tipo de periodismo era a inexistência de magazines diários, a curta duração (normalmente chegavam a publicar sete números ${ }^{1}$ ), o formato livro, a auto manutenção a partir das subscrições ou pela iniciativa de seus editores e a não

1 Criou-se no período a sentença "mal dos sete números" para registrar essa característica. 
SILVA, Cesar Agenor Fernandes da. Representações, vulgarização e imagética científicas na imprensa da corte fluminense do século XIX. Domínios da Imagem, Londrina, v. 10, n. 19, p. 40-75, jul./dez. 2016.

ISSN 2237-9126

disponibilidade de oficinas próprias (IPANEMA; IPANEMA, 1984, p. 14).12 Uma questão que pode ajudar a entender a efemeridade das revistas do período são os seus custos elevados de manutenção. ${ }^{13}$

Isso talvez explique o baixo número de imagens disponíveis na maior parte dos jornais da época. Contudo, isso não retira o impacto que elas poderiam ter causado em um público amplo, não apenas entre os letrados, que puderam, provavelmente, ter tomado contato com imagens de animais diferentes ou mesmo ouvir falar de lugares sequer imaginados anteriormente.

Apesar das dificuldades orçamentárias, o número de publicações periódicas continuou crescendo, sobretudo nos anos 30 do século XIX, pois, nos anos 20, o número foi bem oscilante, indo da grande explosão de publicações de várias matizes nos anos próximos à Independência aos anos magros, como o de 1826,14 no qual havia pouco mais de 6 publicações no Rio de Janeiro, sendo apenas uma revista literária, $O$ Jornal Scientífico. Em 1830, O Beija-Flor publicou artigo intitulado "A Imprensa no Brasil", no qual faz balanço da quantidade de publicações que surgiram no país e na Corte. O texto ainda traz uma questão interessante: a da prosperidade dos negócios referentes à publicação, venda e distribuição de textos.

12 Sobre as oficinas de impressão consultamos o acervo da biblioteca nacional em << http://catalogos.bn.br/>>

13 Luis Otavio Ferreira, pesquisador da Fundação Osvaldo Cruz, em artigo publicado sobre o início da imprensa médica brasileira (1827-1843), na revista Manguinos - história, ciência e saúde, chamou atenção para esse ponto. (FERREIRA, 2004)

14 Nesse ano, eram produzidos na cidade apenas cinco periódicos: Atalaia da liberdade (4/2/ a 3/1826), A malagueta (18/12/1821 a 3/1832), O Spectador brasileiro (28/6/1824 a 21/5/1827). Triumpho da legitimidade (9/12/1825 a 28/01/1826) e, por fim, O verdadeiro liberal: periódico político literário (2/3 a 6/4/1826). Catálogos da Biblioteca Nacional disponíveis em www.bn.br; e CATÁLOGO de periódicos brasileiros microfilmados. Rio de Janeiro: Fundação Biblioteca Nacional, Dep. Nacional do Livro, 1994; FONSECA, Godim da. Biografia do Jornalismo Carioca. Rio de Janeiro: Quaresma, 1941. 
SILVA, Cesar Agenor Fernandes da. Representações, vulgarização e imagética científicas na imprensa da corte fluminense do século XIX. Domínios da Imagem, Londrina, v. 10, n. 19, p. 40-75, jul./dez. 2016.

ISSN 2237-9126

Se os progressos da Imprensa fossem degraus certos de um termômetro para o adiantamento da civilização, podíamos nos felicitar do nosso avançamento, pois que de quatro anos para cá o número das publicações periódicas tem quadruplicado no Brasil. Em 1827 apenas se contavam 12 ou 13, e hoje, conforme a conta tirada da Aurora de sexta-feira do corrente, 54 saem a luz no Império; destes 16 pertencem a Corte. Em 1827 apenas havia 8, portanto o número tem dobrado; é verdade que as revoluções e eclipses são freqüentes neste giro da letra redonda: v. g. uma das publicações enumeradas pela Aurora, La Revue Brésilienne, já desapareceu. Mas outras duas a renderam imediatamente; o Espelho da Justiça, e Le Messager, jornal francês, que saiu a luz duas vezes por semana, a datar do $1^{\circ}$ de Dezembro: este vem preencher o vão que aquela agradável produção deixaria no nosso sistema de periodicidade, aonde a língua francesa, tão usual aqui, deve por força ter um representante.

Aliás fazendo abstração da influência moral que a publicidade exercita para desenvolvimento do espírito público, da educação, e da industria, contentando-nos com 0 produto pecuniário deste ramo de trabalho, acharemos que entre Diretores, Compositores, Impressores, e Distribuidores mais de 200 pessoas são empregadas e sustentadas por 54 publicações, além dos mais ofícios que acham ocasionalmente algum lucro nos trabalhos anexos, e dos mais empregos das imprensas, em obras extensas, ou folhas avulsas, bem como das profissões anexas de Livreiros, e Encadernadores, podendo sem exageração taxar-se a mais de duzentos contos de reis o capital que nisto gira. Uma aquisição industrial de tanta monta, de que não havia sombra, há 9 anos, merece que se apreciem bem as vantagens que a liberdade de imprensa traz consigo, mormente quando se refletir que a impulsão que dá, e luzes que espalha "aprol" das mais industrias, promovem talvez empresas, e melhoramentos, cujo produto, se se pudesse avaliar em cifras, passaria de muito aquele que diretamente dimana da mesma liberdade. (O BEIJA-FLOR, 1830, p.104-106.)

O projeto civilizatório dos letrados oitocentistas tinha, em mais alta conta, a instrução dos homens livres. Era importante que as luzes fossem derramadas sobre todas as classes. A educação no início do século XIX, na concepção dos letrados, não se restringia ao espaço escolar. Nesse 
SILVA, Cesar Agenor Fernandes da. Representações, vulgarização e imagética científicas na imprensa da corte fluminense do século XIX. Domínios da Imagem, Londrina, v. 10, n. 19, p. 40-75, jul./dez. 2016.

ISSN 2237-9126

sentido, os homens de letras lançaram mão de meios variados, indo do jornalismo à oratória, pois acreditavam que exerciam uma ação pedagógica vital para o país.

O auxiliador da indústria nacional (1833), jornal vinculado à "Sociedade Auxiliadora da Indústria Nacional" (fundada em 1832) e dedicado aos agricultores, técnicos e industriais, realçou, no seu texto da apresentação, os progressos das nações civilizadas da Europa com o advento da ciência, da técnica e da indústria e apontou qual seria o caminho que a publicação seguiria

É para concorrer a estes progressos, e para aparecer a realização de bens, que só a propagação das luzes pode produzir no Brasil, que a Sociedade Auxiliadora da Indústria Nacional aqui estabelecida empreende esta publicação periódica de Memórias e Noticias interessantes a todas as classes industriosas. Passa a sua empresa a ser bem acolhida dos Brasileiros interessados na prosperidade do Império e possam igualmente coadjuvá-la com as suas observações e experiências, aqueles nossos Concidadãos, que por seu saber e Patriotismo devem concorrer à glória da nossa Pátria pelo melhoramento da nossa indústria. ( $O$ Auxiliador da Indústria Nacional, 1835, p. 10)

Hipólito da Costa, por exemplo, na abertura de seu incansável Correio Braziliense ou Armazém Literário (1808-1822), destacou o papel que os homens instruídos deveriam assumir diante dos desafios que se apresentavam por todo o território português

O primeiro dever de um homem em sociedade é ser útil aos membros dela; e cada um deve, segundo as suas forças Físicas, ou Morais, administrar, em benefício da mesma, os conhecimentos, ou talentos que a natureza, a arte, ou a educação lhe prestou. O indivíduo que abrange o bem geral de uma sociedade vem a ser 0 membro mais distinto dela: as luzes, que ele espalha, tiram das trevas, ou da ilusão, aqueles, que a ignorância precipitou no labirinto da apatia, da inépcia, e do 
SILVA, Cesar Agenor Fernandes da. Representações, vulgarização e imagética científicas na imprensa da corte fluminense do século XIX. Domínios da Imagem, Londrina, v. 10, n. 19, p. 40-75, jul./dez. 2016.

ISSN 2237-9126

engano. Ninguém mais útil, pois, do que aquele que se destina a mostrar, com evidência, os acontecimentos do presente, e o trabalho dos redatores das folhas públicas, quando estes, munidos de uma crítica sã, e de uma censura adequada representam os fatos do momento, as reflexões sobre o passado, e as sólidas conjecturas sobre o futuro. (CORREIO BRAZILIENSE, 1808)15

Se percorrermosa literatura do período não serão poucos os exemplos desse tipo que poderemos extrair desta estirpe de impresso. Praticamente, sem exceções, as também chamadas "cartas de intenções" estiveram presentes nos primeiros números de cada nova publicação. Em outras palavras,foi comum, nas introduções ou nas epígrafes, os jornalistas enunciarem que seus jornais estavam a serviço das luzes e que, como homens de talento, ou sábios, deveriam exercer um papel importante na sociedade brasileira. Utilizar a razão para promover o bem público.

Outro ponto que também foi ressaltado nestas publicações foi a valorização do conhecimento científico. A Gazeta de Domingo (18391840) valorizou este conhecimento e ressaltou a necessidade do Rio de Janeiro contar com uma publicação semanal que propagasse os conhecimentos e noções das ciências

Os Empresários desta nova publicação, percebendo a falta, que sentia o Rio de Janeiro, de uma Revista semanal, que, ao passo que recreasse a imaginação, o satisfizesse a curiosidade dos habitantes desta Cidade, se propusesse a um fim útil, qual o de propagar os conhecimentos e noções de todas as Ciências; resolveram estabelecê-la, unindo-se a colaboradores de reconhecidas luzes, e talento. (A Gazeta dos Domingos, 1839, p. 1)

${ }^{15}$ Correio Braziliense ou Armazém Literário,v.1, n.1, jun., p.A2, 1808. O Correio Brazileiense foi editado em Londres entre os anos de 1808 e 1822 e circulou em várias localidades do Brasil, em especial no Rio de Janeiro. Fruto dos esforços de Hipólito José da Costa, seu editor e único redator, o Correio desafiou o sistema de censura do império português durante 14 anos ininterruptamente. Além do mais, é considerado o primeiro jornal brasileiro, apesar de não ter sido editado no país. 
SILVA, Cesar Agenor Fernandes da. Representações, vulgarização e imagética científicas na imprensa da corte fluminense do século XIX. Domínios da Imagem, Londrina, v. 10, n. 19, p. 40-75, jul./dez. 2016.

ISSN 2237-9126

A ciência e a técnica, pilares da vida moderna ocidental, foram extremamente valorizadas pela inteligência e pela administração locais do período. Era necessário estudar, compreender e aplicar esses conhecimentos em todos os setores da vida nacional. A ferramenta mais moderna no século XIX para propagar um discurso que valorizasse esses conhecimentos era a imprensa periódica livre. Daí o fato de a veiculação de temas técnico-científicos nos impressos de então ter sido ampla e diversificada, indo da agricultura à astronomia, passando pelas patentes de inventos, métodos de aprendizagem, culinária, medicina, ciências naturais, arquitetura, urbanística, engenharia, indústria e economia política, para ficarmos nuns poucos exemplos. São esses conteúdos e a maneira como foram veiculados que permitem dizer que - papel desempenhado pela ciência e pela técnica no projeto civilizatório para o Brasil foi de primeira grandeza. O que se pretendia era que a razão predominasse na vida e na administração do país, bem como o conhecimento científico e as suas variantes técnicas fossem incorporados amplamente pelos brasileiros, tornando-se habituais entre os homens livres. Só assim, o país atingiria o mesmo patamar da tão invejada civilização europeia. Tendo isso em vista veremos alguns exemplos de conhecimentos veiculados na imprensa periódica.

A partir do descrito partiremos para um breve panorama sobre os conteúdos veiculados, bem como as representações imagéticas impressas nestas folhas púbicas.

\section{Imagens e Ciência no periodismo fluminense das primeiras décadas do século XIX}

A valorização da razão no Brasil coincide com o início da missão civilizatória no país, promovida pela administração joanina. As ações positivas que contaram com a introdução da medicina, da missão 
SILVA, Cesar Agenor Fernandes da. Representações, vulgarização e imagética científicas na imprensa da corte fluminense do século XIX. Domínios da Imagem, Londrina, v. 10, n. 19, p. 40-75, jul./dez. 2016.

ISSN 2237-9126

francesa, da polícia de costumes e, especialmente, da palavra escrita impressa, rapidamente foram abraçadas pelos homens de letras. Os jornais mostram claramente que essa missão, no entanto, prosseguiu ao longo de décadas. O parâmetro era a Europa, ou pelo menos uma Europa idealizada: as novidades, os hábitos, a moda e alguns costumes foram incorporados e rearranjados no cotidiano do brasileiro, as letras, valorizadas e, com isso, a definição de um país, de um Império tropical, passou a ser formulada. A literatura, a história, a geografia, a história natural, entre outros saberes, foram elaboradas tendo como objetivo a prosperidade da jovem nação americana, nação que contou com a pena dos seus bacharéis e com as mãos de homens que cuidadosamente dispunham os caracteres metálicos, a fim de formar palavras, frases, parágrafos, páginas e publicações impressas, tornandoas não só ferramentas, mas agentes ativos e importantes nesse processo.

Foi constante, nas páginas dos periódicos, a defesa da necessidade de se aplicar um trabalho racional aos diversos setores da sociedade brasileira oitocentista, ainda que, muito do que foi veiculado em relação às memórias, 16 melhoramentos e métodos fosse direcionado, sobretudo, para a agricultura. O discurso do Brasil como um "gigante pela própria natureza" e detentor de um enorme potencial natural emergiu no começo do século XIX das penas de José Bonifácio, Hipólito da Costa, José da Silva Lisboa e de toda uma leva de intelectuais do período pré e imediatamente posterior à Independência do país.

O Jornal Scientífico, em 1826, trouxe alguns artigos que tratavam do tema, como os ensaios "Ciências e Artes" e "História Natural". A

\footnotetext{
${ }^{16}$ Alguns dos artigos técnicos recebiam o nome de memória, como "Memória sobre a cultura dos algodoeiros, por Manoel Arruda da Câmara". O Patriota, v.1, n.1, 1813, p.22.
} 
SILVA, Cesar Agenor Fernandes da. Representações, vulgarização e imagética científicas na imprensa da corte fluminense do século XIX. Domínios da Imagem, Londrina, v. 10, n. 19, p. 40-75, jul./dez. 2016.

ISSN 2237-9126

defesa e a necessidade de ampliação de tal conhecimento, especialmente no que toca à aclimatação de plantas, foi insistentemente defendido, não apenas pelos redatores do Scientifico, mas por outros jornalistas ao longo dos primeiros decênios do século XIX. Não foi por acaso que o tema das plantas esteve sempre associado à Agricultura e ao clima do país. De acordo com os redatores

A História Natural oferece inumeráveis produtos dos três reinos animal, vegetal e mineral, cujas descrições curiosas e profícuas nos fornecem avultadíssimo cabedal, para desempenharmos, com profusão, grande parte do que temos prometido; porém a seleção no aproveitamento de tais produtos, e de suas respectivas descrições, será sempre para nós objeto de suma atenção, pois que, d'entre eles escolhemos os que reputamos mais análogos aos quesitos físicos deste Império, e mais condizentes ao progresso dos melhoramentos de que ele é superabundantemente suscetível.

[...]

A transplantação de exóticas plantas de diversos países do mundo conhecido, que mais vantajosas sejam para os diferentes e necessários usos e consumos da vida humana, - e a climatização e propagação delas n'aquelas províncias deste vasto Império, cujos requisitos de terrenos e de climas mais analogia tiverem com os de seus originários países, d'onde possam importar, parecenos objeto digno de grandes e muito zelosos cuidadosos, esforços e desvelos, tanto do Governo, como de todas as classes de cidadãos do fecundíssimo Brasil; [...] no todo das 19 Províncias deste assombroso e invejado Império; e como até na simples descrição de algumas de tais plantas, por meio da imprensa (que é tudo quanto está ao nosso alcance) se faz, segundo entendemos, relevante serviço ao Brasil, imperiosa razão, justo motivo por que passamos a dar instrutivas, curiosas e circunstanciadas notícias e descrições, tanto d'aqueles produtos do reino vegetal, que mais interessantes se nos afiguram, como dos do reino animal, assaz preciosos para - Brasil. (JORNAL CIENTIFICO, ECONOMICO E LITTERARIO, $1826)^{17}$

\footnotetext{
${ }_{17}$ Jornal Scientifico, Economico e Litterario, n.2, mai, 1826, p.92-97.
} 
SILVA, Cesar Agenor Fernandes da. Representações, vulgarização e imagética científicas na imprensa da corte fluminense do século XIX. Domínios da Imagem, Londrina, v. 10, n. 19, p. 40-75, jul./dez. 2016.

ISSN 2237-9126

A reprodução das imagens nas ciências naturais passou a se balizar em parâmetros mais rigorosos sobre a representação "do real" na passagem do século XVIII para $\bigcirc$ XIX. Ampla e fortemente amparadas nas descrições dos viajantes naturalistas - que deveriam falar em nome da humanidade -, as viagens científicas tinham por objetivo classificar e nomear o mundo natural. A mudança de perspectiva ocorreu, segundo a historiadora Lorelai Kury (2008, p.321323), pois

a tradição das viagens, desde a época das Luzes, é a busca de registros exatos. O confronto de testemunhos, a distinção essencial entre 'ver' e 'ouvir dizer', o emprego de instrumentos de medição e a utilização de instruções para os viajantes acompanham 0 processo de constituição da viagem como prática científica, concebida como sendo útil e confiável. Para tanto, a construção de conhecimento científico passava a ser vista como atividade coletiva, feita por diversos especialistas, cujo conteúdo pudesse circular entre pessoas e entre países. A ilustração traçou contornos da viagem como atividade útil, de interesse universal

[...]

Mudam igualmente as exigências com relação às habilidades necessárias para participar de uma expedição científica. O viajante ideal deveria saber desenhar, embalar, corretamente produtos de historia natural, empalhar animais, confeccionar herbários, recolher sementes, dissecar animais e plantas. Estas habilidades seriam uma garantia para que seu trabalho pudesse ser aproveitado por outros, mesmo os sedentários habitantes da Europa, incluindo aí os naturalistas de gabinete. Uma das funções essenciais dos viajantes seria exatamente a de tornar objetos e informações peças adequadas para serem transportadas e colecionadas de forma eficiente.

[...] o desenho e a pintura ocupavam lugar essencial nas viagens do século XIX. As grandes expedições sempre puderam contar com a presença de artistas.

Os trabalhos dos naturalistas estrangeiros, publicados em suas relações de viagem, contribuíram de maneira ímpar para a formulação 
SILVA, Cesar Agenor Fernandes da. Representações, vulgarização e imagética científicas na imprensa da corte fluminense do século XIX. Domínios da Imagem, Londrina, v. 10, n. 19, p. 40-75, jul./dez. 2016.

ISSN 2237-9126

de uma cultura científica no país. Todo o conteúdo veiculado nas páginas da imprensa periódica tinha por objetivo não apenas a familiarização dos leitores com essas temáticas, mas a incorporação desses conhecimentos a um modo de vida que se queria para os homens livres, qual seja, viver de acordo com os preceitos da ilustração para poder aplicar a razão à civilização do Brasil. Os diários de viajantes naturalistas em muitas ocasiões serviram não apenas de fonte de inspiração, mas também de material primário para reprodução e veiculação dos saberes técnico-científicos.

Em 1816, o Correio Braziliense veiculou a seguinte opinião do seu redator - que representa a de muitos outros dos seus contemporâneos sobre o importante papel dos viajantes estrangeiros e de suas narrativas para o Brasil

Por mais prejudicado que pareça um estrangeiro, que publica as suas viagens a um país nascente, como é o Brasil, sempre os naturais do país o devem ouvir; e com tanta mais atenção, quanto mais acerbas fazem as acusações e críticas que ele fizer; porque é este o meio de emendar muitos males do Estado. (CORREIO BRAZILIENSE, 1812) 18

[...]

Não pode ser indiferente aos habitantes do Brasil as reflexões, que fazem as pessoas sensatas, que visitam o seu país; sobre os seus costumes, legislação, comércio, \&c. e tanto mais, quanto um estrangeiro pode ver muitos objetos por diferentes faces, e melhor do que os naturais, a quem os prejuízos, e o hábito, muitas vezes, impedem ver seus próprios defeitos. É verdade que também os prejuízos ou ignorância desses viajantes podem induzi-los a perverter os fatos; mas sempre é bom ouvi-los, e refletir no que eles dizem. (CORREIO BRAZILIENSE, 1816) ${ }^{19}$

O conselho dado por Hipólito da Costa no Correio Braziliense foi acolhido por seus contemporâneos e, também, pelos homens que se

${ }_{18}$ Correio Braziliense, v.9, n.50, jul., 1812, p.101

${ }^{19}$ Correio Braziliense, v.16, n.93, fev., 1816, p.141-148 
SILVA, Cesar Agenor Fernandes da. Representações, vulgarização e imagética científicas na imprensa da corte fluminense do século XIX. Domínios da Imagem, Londrina, v. 10, n. 19, p. 40-75, jul./dez. 2016.

ISSN 2237-9126

dedicaram a produzir folhas públicas. Porém, diferentemente do que Hipólito asseverou, não foram apenas as visões sobre os hábitos, comportamentos e os aspectos políticos produzidos por viajantes estrangeiros que foram aproveitados pelos periodistas, mas também sua produção em ciências naturais.

Era comum a reprodução e tradução de conteúdos extraídos de revistas europeias - nem sempre citadas -, como notícias de guerras, tratados e, especialmente, avanços técnicos e científicos. Muitos dos textos reproduzidos tratavam-se de produções de viajantes naturalistas. Alguns jornais, como O Auxiliador da Industria Nacional, preenchiam quase todas as suas páginas com esse tipo de artigo. Os textos originais veiculados tinham um caráter eminentemente ensaístico, o que acabou por criar um padrão na vertente periódica das Belas Letras. Essa característica deu a tônica até meados do século XIX, mais especificamente até meados da década de 50, quando a prática jornalística se alterou. O formato dos periódicos passou, então, ao tamanho grande e o número de diários aumentou consideravelmente. Além disso, houve uma modificação na maneira de lidar com a notícia e com a informação, que passaria a ser recebida em maior escala nas décadas de 60 e 70, com a chegada do telégrafo, e tratada por "profissionais" (IPANEMA; IPANEMA, 1984; SODRÉ, 1977; VIANNA, 1945; SIMÕES JUNIOR, 2006). Outro ponto que também merece destaque é o da especialização dos autores. Na segunda metade do século, um autor não escrevia mais sobre tudo, mas sobre temas específicos. Esse movimento tem sua emergência nos anos 50 do oitocentos e pode ser claramente visualizado em revistas como a Guanabara (1850) e a Minerva Brasiliense (1843-1845).

Retomando a questão da vulgarização científica no período abordado, temos o exemplo da Gazeta dos Domingos, revista enciclopédica semanal, editada em 1834. Ela trouxe em suas páginas 
SILVA, Cesar Agenor Fernandes da. Representações, vulgarização e imagética científicas na imprensa da corte fluminense do século XIX. Domínios da Imagem, Londrina, v. 10, n. 19, p. 40-75, jul./dez. 2016.

ISSN 2237-9126

uma série de descrições de animais como cobras, rinocerontes, ursos, leões, águias, etc. As descrições eram acompanhadas de pequenas ilustrações e, por vezes, de poemas, que ligavam o conhecimento da História Natural com a literatura.

A Gazeta dos Domingos foi um dos magazines que apresentou maior variação temática dentro de uma mesma edição. Em suas 12 páginas, publicadas semanalmente, tratou-se de política, literatura, história natural, balancetes comerciais, arquitetura, descrições de cidades europeias e americanas, culinária, habitação, entre outros. Seu subtítulo deixa claro seu objetivo, ser uma enciclopédia. O modelo da Gazeta, de acordo com seus redatores, era inspirado nas revistas britânicas. As páginas da Gazeta eram compostas por duas colunas, no entanto, as ilustrações ficavam dispostas entre os textos, e não em páginas separadas, prática comum provavelmente por causa dos custos tipográficos. A maior parte das edições conta com desenhos, seja de animais, construções, plantas ou mesmo de representações do crânio de seres humanos.

No quesito técnica, alguns novos inventos foram noticiados e alguns outros já existentes, explicados, como no caso do barco a vapor. Na seção dedicada à arquitetura, construções como a Basílica de São Pedro, o Castelo de Windsor, o Coliseu, o Palácio de Versalhes, por exemplo, foram descritos e ilustrados. O objetivo era apresentar ao brasileiro as principais construções e paisagens urbanas históricas ou modernas do mundo. Ao final de cada número, uma página era dedicada às informações econômicas/comerciais, como o câmbio em relação a Londres, Paris e Hamburgo. Outros indicadores apontavam o preço de exportação e importação de diversos gêneros, que iam da farinha de mandioca ao aço fino. Informações sobre a duração em horas dos dias da próxima semana, fases da lua, marés e até 
SILVA, Cesar Agenor Fernandes da. Representações, vulgarização e imagética científicas na imprensa da corte fluminense do século XIX. Domínios da Imagem, Londrina, v. 10, n. 19, p. 40-75, jul./dez. 2016.

ISSN 2237-9126

informações astrológicas (entrada do Sol nas casas do Zodíaco) também podiam ser lidas nessa última página.

A Gazeta dos Domingos, em 1839, na partição dedicada à História Natural, publicou uma série de textos sobre a variação da raça humana, baseados no que escreveu o filósofo e naturalista do séc. XVIII, Georges Cuvier.20 Os textos descreviam desde feições físicas até aspectos morais de "raças" diferentes - caucasianos, nativos americanos, mongóis (asiáticos), negros e outras - propostas pelo teórico. $O$ artigo abre da seguinte maneira

\section{Sobre o homem.}

Disse também Deus: façamos o homem á nossa imagem, e semelhança, o qual presida aos peixes do mar, às aves do céu, às bestas, e a todos os répteis que se movem sobre a terra, e domine em toda a terra.

E criou Deus o homem á sua imagem: fez à imagem de Deus, e criou o macho e a fêmea.

Deus os abençoou, e Ihes disse: Crescei, e multiplicai-vos, e enchei a terra. Gênesis. Cap. $1^{\circ}$ v. 26 a28.

A distribuição geográfica de entes animados é um ramo da História Natural, que somente nestes últimos anos tem atraído a atenção dos filósofos.

O célebre Blumenbach foi quem primeiramente generalizou os numerosos fatos referentes à fisiologia do homem, e estabeleceu, com provas incontestáveis, que as suas variedades podem classificar-se debaixo de certos característicos de formação distintos uns dos outros tanto na sua organização física, como em sua distribuição geográfica.

Fosse por causa de prejuízos, ou pela dificuldade de percorrer toda a extensão do vasto campo zoológico, pelo espírito de um único indivíduo, o certo é que a geografia de entes animados tem jazido quase em total abandono.

20 As doutrinas de Cuvier foram bem aceitas pelos periodistas, pois mais de um jornal publicou artigos fazendo referência ao naturalistas, chegando até mesmo à composição de pequenas bibliografias, como a publicada em A Nova Minerva: revista dedicada as sciencias, artes, litteratura e costumes, t.1, n.1, 11 fev., 1846, p.8. 
SILVA, Cesar Agenor Fernandes da. Representações, vulgarização e imagética científicas na imprensa da corte fluminense do século XIX. Domínios da Imagem, Londrina, v. 10, n. 19, p. 40-75, jul./dez. 2016.

ISSN 2237-9126

Detalhes isolados, referentes a alguns países, classes, ou famílias, tem sido analisados satisfatoriamente; porém, ainda falta quem generalize esses fatos, tornando-os profícuos à descoberta das leis da criação.

A tarefa de averiguar a posição de algumas classes em um lugar ou país determinado pode ser unicamente considerada como uma simples investigação acerca de sua distribuição local; mas quando as nossas indagações saírem destes apertados limites a fim de abranger maior porção do nosso globo, e combinarem a relação entre os seus animais com a de outras porções, entraremos desde esse momento, no assunto vastíssimo da distribuição geográfica.

As averiguações que dizem respeito à distribuição física adquirem um grau de importância, quando não dirigidas ao mundo animal, maior de que o é quando se destinam ao vegetal, por muito interessante que este seja; porque, não somente achamos que o número de animais é incalculavelmente maior que 0 das plantas, como também a sua posição natural, dependendo de uma multiplicidade de causas correntes, encontra-se ser mais distintamente caracterizada.

Iremos apresentando aos nossos leitores, em primeiro lugar, um esboço das particularidades físicas do homem em todas as suas variedades. Daremos depois breve notícia sobre as regiões habitadas pelas suas diferentes raças.

As raças humanas dividiam-se, segundo a teoria de Cuvier veiculada no periódico, em 3 grupos "primários"

\section{Variedade da raça humana.}

As variedades da raça humana, conforme a opinião do mais distinto anatomista do sistema comparativo, podem todas incluir-se em três divisões primárias, entre as quais, há exemplos simbólicos de notáveis subdivisões. Estas classificações o Barão Cuvier distingue pela forma seguinte:

$1^{\text {a. }}$ A variedade branca ou Caucasiana.

$2^{a}$. A variedade cor de cobre, ou Mongoleana.

$3^{a}$. A variedade negra, ou Etiopiana.

A classificação proposta pelo célebre Blumenbach, posto que aparentemente diversa é, todavia, uma modificação da que estabeleceu Mr. Cuvier.

Mr. Blumenbach dividiu a classe etiopiana em 3 partes distintas $-1^{a}$ a Americana; $2^{a}$ a Negra; $3^{a}$ a Malaia. 
SILVA, Cesar Agenor Fernandes da. Representações, vulgarização e imagética científicas na imprensa da corte fluminense do século XIX. Domínios da Imagem, Londrina, v. 10, n. 19, p. 40-75, jul./dez. 2016.

ISSN 2237-9126

Mr. Cuvier individualiza essas raças adicionais; porém considera as suas peculiaridades menos salientes que as de suas duas primeiras.

Vamos passar uma ligeira revista sobre as peculiaridades físicas e morais destes grupos da nossa espécie, sem emitir opinião alguma a respeito da questão acima referida.

A primeira raça tratada nessa série de artigos foi a Caucasiana. A descrição extrapola a questão física e parte para a explanação dos "sentimentos morais" e dos motivos pelos quais os caucasianos dominavam as demais raças.

A raça caucasiana é simbolicamente caracterizada pela pele branca, faces rosadas, cabelo abundante, flexível, comprido, freqüentemente anelado e laureado, muita barba, rosto pequeno, ovalado e comprido, com as feições muito conspícuas, a testa espaçosa; o crânio grande e elevado; nariz fino; a boca pequena.

Os sentimentos morais e as capacidades intelectuais dessa raça têm-se desenvolvido até ao auge da perfeição, de que a natureza humana tem dado provas. As nações mais civilizadas, tanto dos tempos antigos como modernos, tiveram a sua nascença da raça Caucasiana, a qual, excetuando casos de resistência física em ponto extraordinário, tem exercido o domínio sobre todas as mais raças. As poderosíssimas nações da antiguidade, e a força que the não cede em proporção, das modernas concentradas na Europa, provam evidentemente a primazia desta raça em tudo que diz respeito à parte imaterial do homem, e no que constitui formidável para com os seus semelhantes; enquanto que, a par da marcha dos tempos, se nota um melhoramento progressivo em tudo que indica talento e inteligência.

A raça caucasiana supõe-se, como se deduz deste nome, ter saído daquela cordilheira de montanhas entre os mares Preto e Cáspio.

Esta suposição coaduna-se com tudo que nos esclarece sobre o local da morada de nossos originais progenitores, e ainda mais se confirma pela razão de serem os habitantes daquelas regiões, até o dia presente, os mais bem proporcionados e elegantes de todos os habitantes do mundo inteiro. (GAZETA DOS DOMINGOS, n. 2,1839, p. 7) 
SILVA, Cesar Agenor Fernandes da. Representações, vulgarização e imagética científicas na imprensa da corte fluminense do século XIX. Domínios da Imagem, Londrina, v. 10, n. 19, p. 40-75, jul./dez. 2016.

Ao final dos artigos eram publicadas ilustrações, como no caso da Figura 1.

FIGURA 1 - Gravuras que representam os tipos de feições e crânios das "raças" humanas
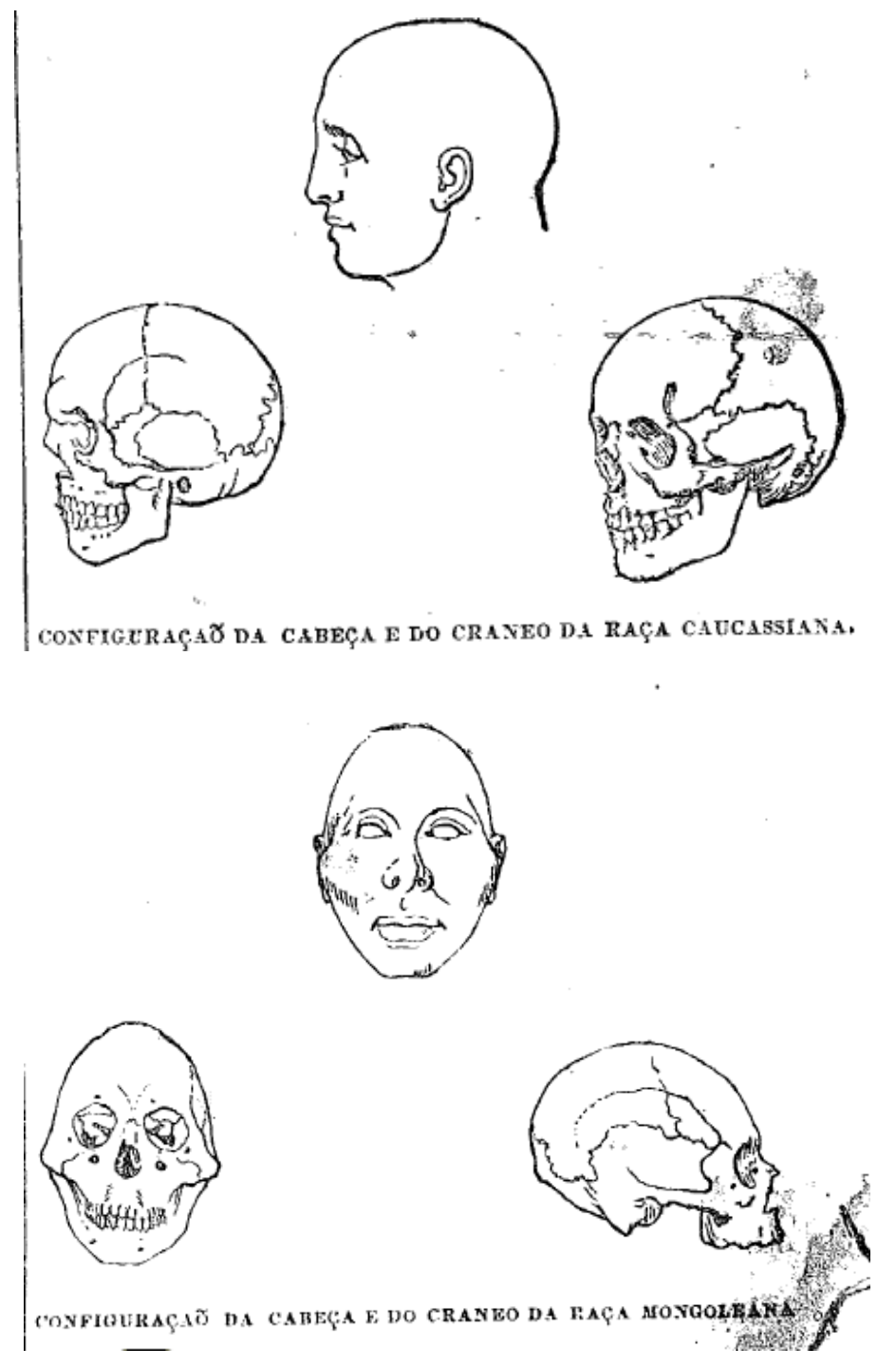
SILVA, Cesar Agenor Fernandes da. Representações, vulgarização e imagética científicas na imprensa da corte fluminense do século XIX. Domínios da Imagem, Londrina, v. 10, n. 19, p. 40-75, jul./dez. 2016.

ISSN 2237-9126

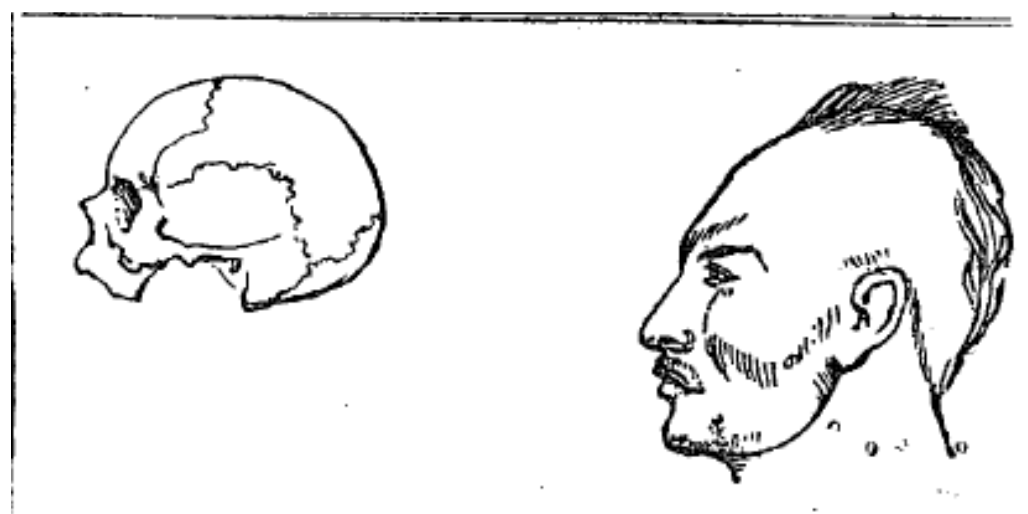

CONFIGURAÇAÕ DA CABEÇA E DO CRANEO DA RAÇA AMERICANA.

FONTE: Gazeta dos Domingos: revista enciclopédica semanal do Rio de Janeiro. Rio de Janeiro: Tip. Americana, 1839, n.1, 2 e 4.

Outras áreas, além das relacionadas às ciências naturais, também foram veiculadas nas páginas da imprensa fluminense. No artigo intitulado "Ciências Sociais", O Globo, em 1844,divulgou as ideias do socialista utópico François Marie Charles Fourier (1772-1837), que para eles era o homem que mais se preocupava com a organização e finalidade do trabalho. "Nós publicaremos uma exposição de sua doutrina; por nos parecer melhor resumir as idéias deste gênio tão fecundo, e tão poderoso." O objetivo da veiculação das idéias de Fourier era divulgar as suas teorias, segundo o texto, "inda muito estranhas no Brasil", mas foi ressaltado que "não pretendemos ocupar o lugar de campeão de todas as opiniões emitidas por $C$. Fourier e seus discípulos." (O GLOBO, n.1, out., 1844, p.4)

Na matéria que ocupou as páginas 3, 4 e 5, foram expostas de maneira sintética as principais doutrinas do filósofo, em especial a do Falanstério. Algumas idéias sobre a organização e a criação de falanstérios em certas regiões do mundo ocidental, como nos Estados Unidos e na Europa, foram descritas nesse artigo que, entre outras coisas, contava com ilustrações do lugar utópico criado por Fourier. Nas páginas de $\mathrm{O}$ Globo, o falanstério, tratado com muito entusiasmo, teria a seguinte finalidade: 
SILVA, Cesar Agenor Fernandes da. Representações, vulgarização e imagética científicas na imprensa da corte fluminense do século XIX. Domínios da Imagem, Londrina, v. 10, n. 19, p. 40-75, jul./dez. 2016.

ISSN 2237-9126

() GLOBO

5

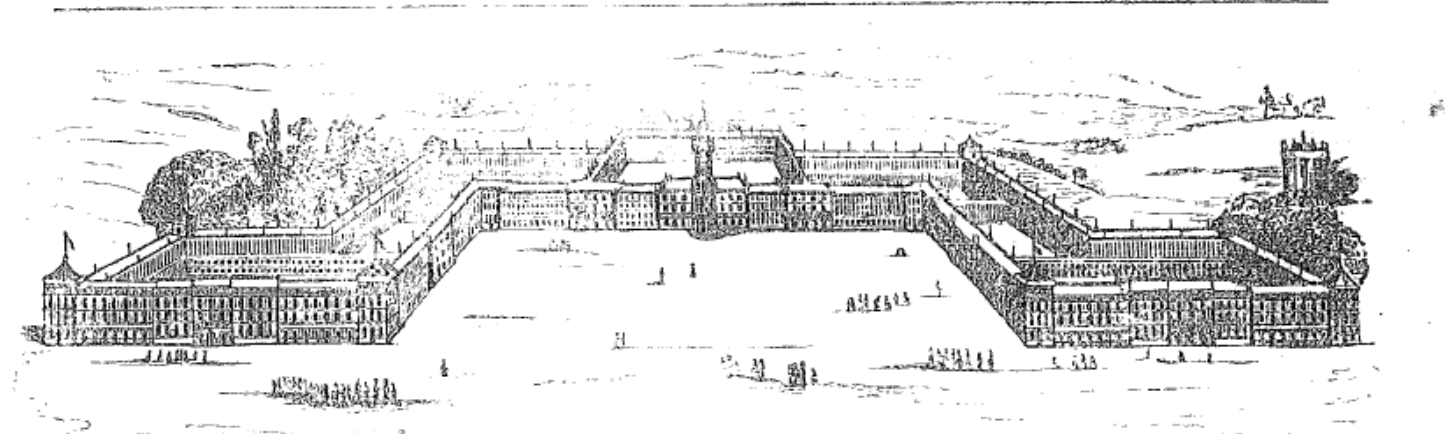

Independência absoluta. Ninguém será coagido em suas empresas industriais, seus gostos pessoais, emprego de sua fortuna; cada um pode a todo o instante deixar um falanstério por outro que lhe oferecer prazer, e trabalho a seu gosto.

Hotéis, teatros, bibliotecas e museus etc., etc., que a administração de cada falanstério é interessada a aumentar e melhorar constantemente, procurarão ao pobre falanstério gozos desconhecidos aos privilegiados do velho mundo.

Já falanstérios se elevam na América, se preparam a fundar na velha Europa. Os resultados dos primeiros farão construir mil outros, e mudarão a face do mando. A idade de ouro vai renascer. A harmonia substituirá a discórdia. A nova Jerusalém descerá sobre a terra. Deus habitará entre nós.

Honra a Fourier. (O GLOBO, n.1, out., 1844, p. 5)

Gilberto Freyre, em Sobrados e Mucambos e em Um engenheiro francês no Brasil, aponta brevemente que ideias socialistas circularam e tiveram certa ressonância pelo país no século XIX, especialmente pela presença dos franceses, que trouxeram tais ideias de seu país natal. Operários derrotados "nas revoluções de 1830 e ameaçados pela opressão e pelo desemprego rumaram para o Brasil na década de 1840 do século XIX, determinados a formar um falanstério" (GALLO, 2009, P. 148).

Os fourieristas franceses no Brasil divulgaram suas ideias através de publicações de panfletos e queriam atingir as classes desfavorecidas. 
SILVA, Cesar Agenor Fernandes da. Representações, vulgarização e imagética científicas na imprensa da corte fluminense do século XIX. Domínios da Imagem, Londrina, v. 10, n. 19, p. 40-75, jul./dez. 2016.

ISSN 2237-9126

Seu principal líder foi Benoist-Jules Mure, um ex-sansimoniano21 que encaminhou cartas ao Imperador na tentativa de fundar uma colônia industrial e um falanstério no país. Ao contrário do que se possa imaginar, a ideia foi bem acolhida pelas autoridades brasileiras, especialmente no que diz respeito à implementação de uma colônia industrial, pois, como já foi dito, o desenvolvimento da indústria era objetivo comum dos homens de letras e dos governantes. Um falanstério, de vida curta, chegou a ser erguido em Saí, atual distrito de São Francisco do Sul, em Santa Catarina. No entanto, o fracasso da

21 Interessante observar que o CorreioBrazilenese publicou, na seção de Litteratura e Sciencias, entre os anos de 1816 e 1820, as doutrinas do economista suíço Jean-Charles Simonde (1773-1842), autor considerado pelos manuais de teoria econômica como um dos pensadores que desenvolveram embrionariamente o pensamento socialista, sendo o responsável, em 1819, pela introdução do termo 'proletário' enquanto categoria de análise. A título de ilustração, fazemos uma referência ao filósofo Karl Marx, que cita um dos estudos do suíço em nota do "18 Brumário de Luis Bonaparte". Entretanto, as idéias de Simonde veiculadas pelo Correio eram referentes a seu ensaio "Princípios de Economia Política aplicados à Legislação do Comércio". Os Princípios..., de Simonde, em sua parte "universal", eram um "manual" sobre o tema, pois tratou de descrever e analisar a origem da riqueza das nações, (revisando questões colocadas por Smith como a do trabalho produtivo e improdutivo), as leis que regiam o comércio, passando pela problemática dos preços, monopólios e a aplicação das Colônias produtivas. Na conclusão da tradução comentada do livro, o ponto principal das lições dos Princípios é exposta: "Os homens não têm querido reconhecer que as regras da moral eram também as da política: têm sufocado a voz de suas consciências, que Ihes gritava que não fundassem o seu poder sobre o mal de seus semelhantes; e rejeitando esta advertência saudável, desconheceram a voz da razão, que também o repetia; porque esta lhes gritava, com não menos força, que nunca arruinariam a tranqüilidade, não destruiriam a liberdade de seus irmãos, sem experimentar, no mesmo instante, que numa justa reação vinha atacar sua própria riqueza, sua indústria, seu descanso, e sua liberdade; sem se convencer que o pior político era o que fazia aos outros mais mal. [...]. Eu me julgaria feliz, se pudesse contribuir, atrair a atenção do Governo da França, para o exame de uma teoria cuja aplicação pode ser tão importante à sua prosperidade. Sem dúvida não tardará muito tempo a trazer para esta parte, como tem feito para todas as outras, suas vistas reparadoras; e podemo-nos lisonjear de receber bem depressa dele uma legislação comercial, conforme aos progressos das luzes, aos princípios de uma sã economia política, aos sentimentos de beneficência, que os diversos povos se devem uns aos outros [...]" (CORREIO BRAZILIENSE, v.25, n.151, dez., 1820, p. 688-690). 
SILVA, Cesar Agenor Fernandes da. Representações, vulgarização e imagética científicas na imprensa da corte fluminense do século XIX. Domínios da Imagem, Londrina, v. 10, n. 19, p. 40-75, jul./dez. 2016.

ISSN 2237-9126

experiência francesa pode ter ocorrido em razão de o governo não ter contribuído para que a iniciativa fosse muito adiante. Assim que 0 falanstério foi fechado, os homens envolvidos na empresa foram empregados no Rio de Janeiro (GALLO, 2009, p. 153).

Entretanto, artigos sobre como ampliar, melhorar e aproveitar a cana-de-açúcar foram os campeões em recorrência durante a primeira metade do século XIX. Os textos, na maioria das vezes, descreviam os variados tipos da planta e as diferentes maneiras de cultivo praticadas pelo mundo, como nos Estados Unidos da América, por exemplo. Em 1813, O Patriota publicou textos sobre cana e engenhos.Duas décadas depois, em 1835, o jornal Miscelânea Científica abriu seus artigos com um texto sobre o mesmo tema, assim como praticamente todas as publicações que se dedicavam a veicular conhecimentos técnicocientíficos. A Agricultura, em suma, foi um tema de grande destaque nesses magazines, cujos autores estavam interessados tanto em racionalizar e modernizar o campo, como em civilizar os habitantes dos mais longínquos rincões do país. 22 o Miscelânea... trouxe uma série de gravuras que representavam todo o processo de produção do açúcar, desde o cultivo ao trabalho no engenho (como podemos ver na Figura 2)

22 A respeito de outras publicações que se voltavam ao tema, consultar os trabalhos do historiador Rafael Bivar de Marquese. (MARQUESE, 2004; MARQUESE, 1999). 
SILVA, Cesar Agenor Fernandes da. Representações, vulgarização e imagética científicas na imprensa da corte fluminense do século XIX. Domínios da Imagem, Londrina, v. 10, n. 19, p. 40-75, jul./dez. 2016.

ISSN 2237-9126

Figura 2 - representação gráfica do processo de produção do
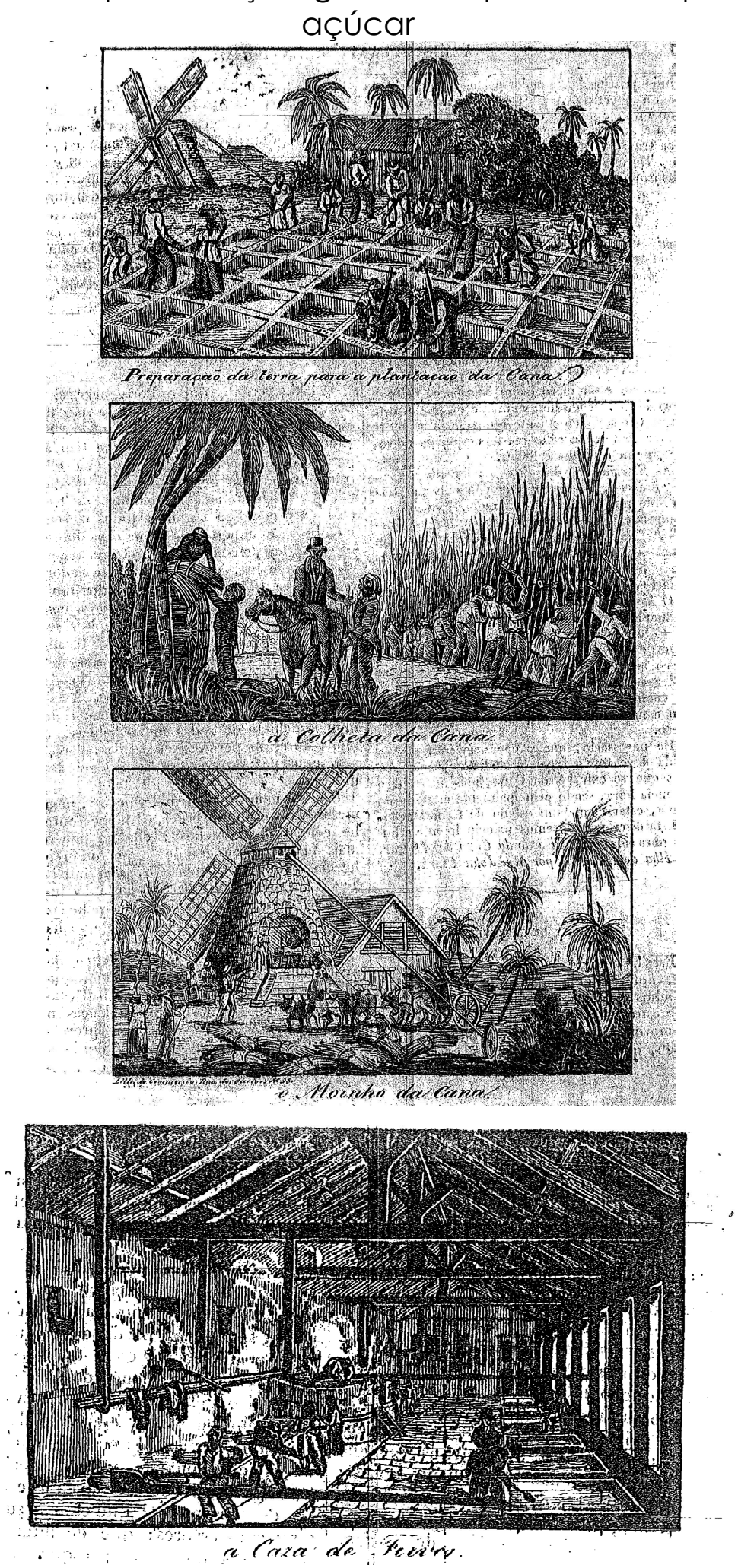

Fonte: A miscelânea scientifica. Rio de Janeiro: Garcia Gimenez, n.1, p.3 e 5, 8 de ago., 1835 
SILVA, Cesar Agenor Fernandes da. Representações, vulgarização e imagética científicas na imprensa da corte fluminense do século XIX. Domínios da Imagem, Londrina, v. 10, n. 19, p. 40-75, jul./dez. 2016.

ISSN 2237-9126

A exemplo do que foi dito em relação ao tipo de matérias publicadas na imprensa literária, além da Gazeta dos Domingos, outros periódicos também reproduziram textos nos quais descreviam animais da fauna de outras localidades. Rinocerontes, elefantes, lobos, entre outros foram descritos. Alguns até receberam ilustrações que ajudariam seus leitores a visualizá-los após extensa descrição de todas as suas características (habitat, anatomia, hábitos alimentares, etc.). Como pode ser visto na figura 3.

Muito provavelmente os leitores, sobretudo os mais jovens, que tomaram contato com essas gravuras e as descrições nunca haviam ouvido falar destas espécies animais e tão pouco dos seus locais de origem. Estabelecia-se, provavelmente, um novo leque de representações sobre o mundo além-atlântico. Vale ressaltar que as descrições dos animais tentavam ser o mais detalhistas possíveis. No caso das cobras cascáveis, por exemplo, o texto publicado em duas partes, nas edições 2 e 3, respectivamente, lançadas nos dias 8 e 15 de agosto de 1835,23 do Miscelânea Scientífica, descreve até mesmo as bolsas acima das presas que serviam de reservatório para o veneno. Até mesmo as concepções atuais de que cada anel da calda destas serpentes representariam um ano de sua vida constava da descrição.

${ }^{23}$ Infelizmente a $4^{a}$ edição do jornal se perdeu no tempo e a conclusão do texto que descreve as cascáveis não pode ser lida. 
SILVA, Cesar Agenor Fernandes da. Representações, vulgarização e imagética científicas na imprensa da corte fluminense do século XIX. Domínios da Imagem, Londrina, v. 10, n. 19, p. 40-75, jul./dez. 2016.

ISSN 2237-9126

Figura 3 - Gravuras representando um Rinoceronte, um Elefante e uma cobra Cascavel

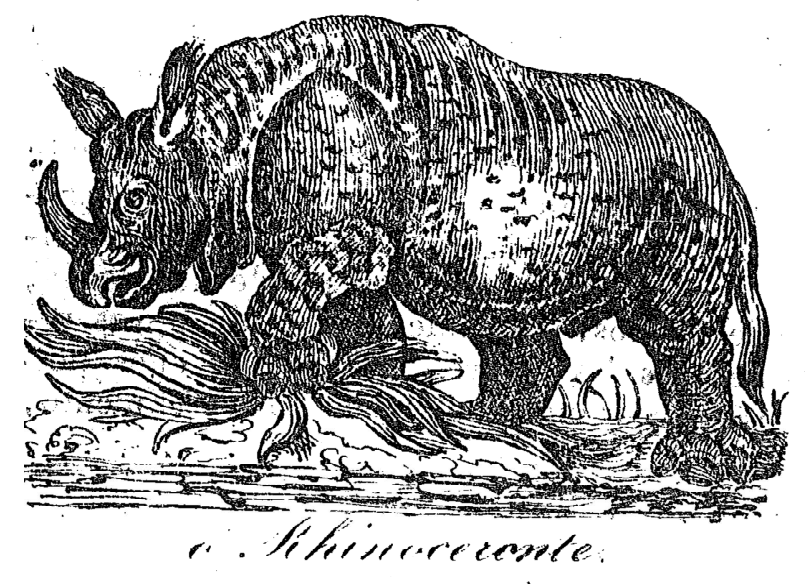

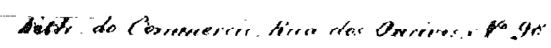
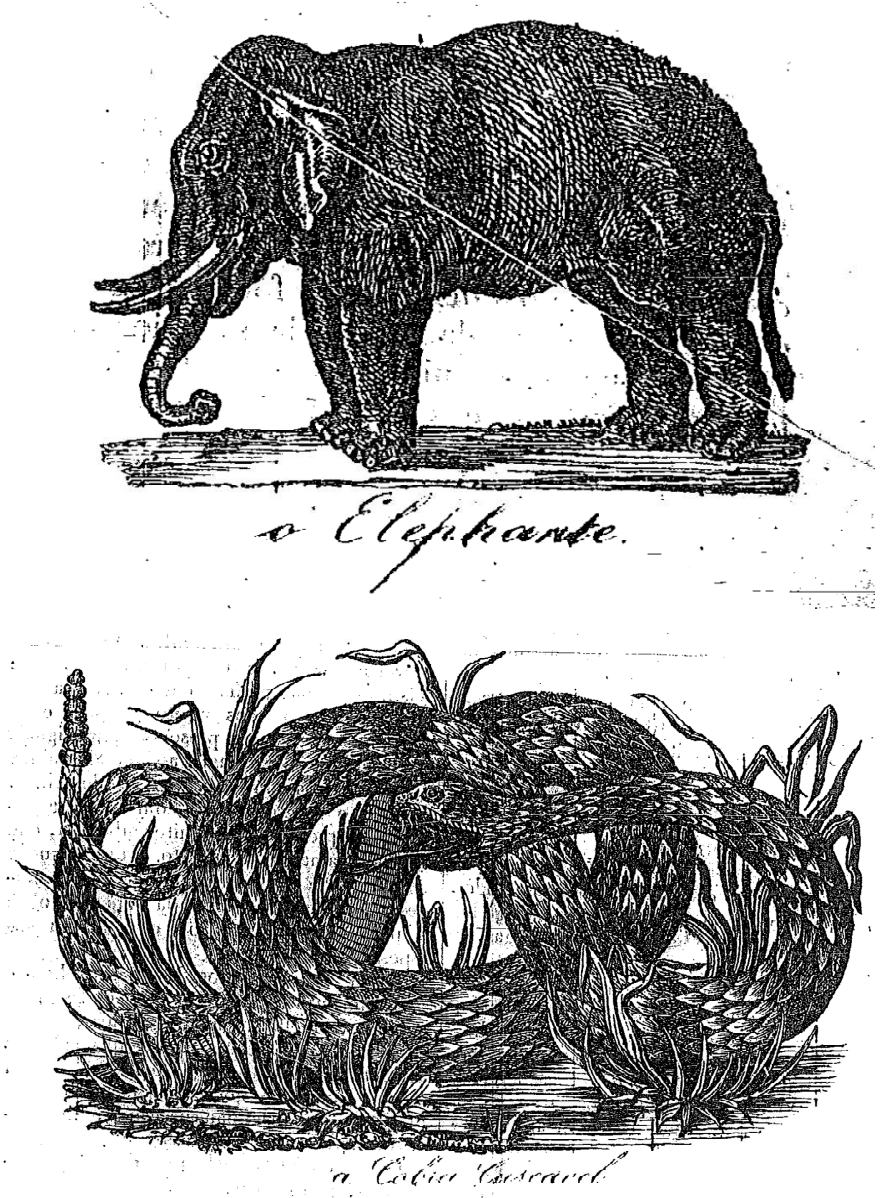

Fonte: A miscelânea scientifica. Rio de Janeiro: Garcia Gimenez, n.2, p.5, 8 de ago., 1835. 
SILVA, Cesar Agenor Fernandes da. Representações, vulgarização e imagética científicas na imprensa da corte fluminense do século XIX. Domínios da Imagem, Londrina, v. 10, n. 19, p. 40-75, jul./dez. 2016.

ISSN 2237-9126

Como mencionado, as publicações periódicas também apresentavam detalhes arquitetônicos de edifícios ou mesmo de cidades inteiras. Palácios, catedrais, praças, monumentos, pontes e também elementos geográficos como vulcões, cânions e vales, como podemos observar nas figuras 4 e 5 .

Figura 4 - Gravura representando a Vista da Catedral da cidade do México

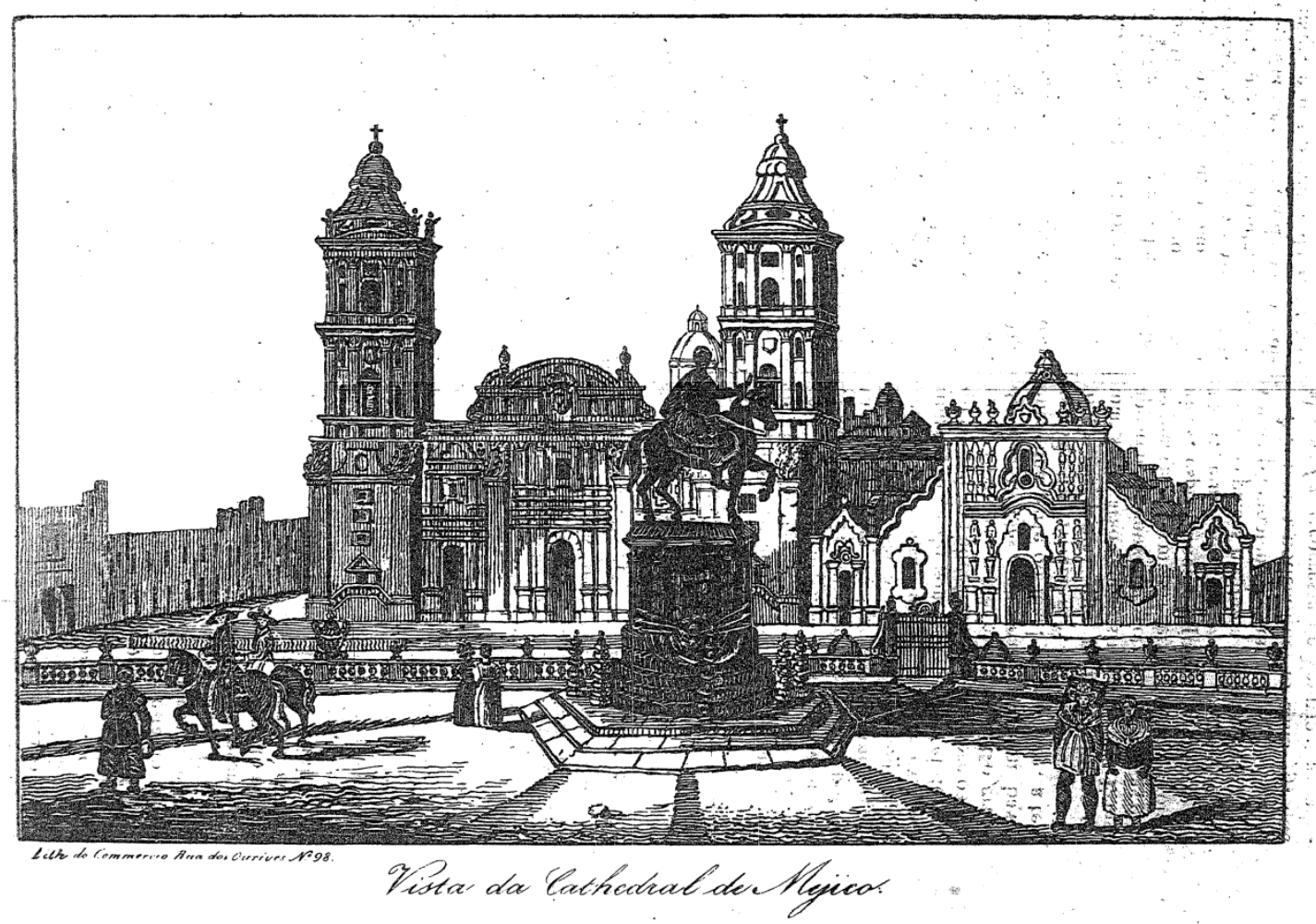

Fonte: A miscelânea scientifica. Rio de Janeiro: Garcia Gimenez, n.3, p.6, 15 de ago., 1835 
SILVA, Cesar Agenor Fernandes da. Representações, vulgarização e imagética científicas na imprensa da corte fluminense do século XIX. Domínios da Imagem, Londrina, v. 10, n. 19, p. 40-75, jul./dez. 2016.

ISSN 2237-9126

Figura 5 - Representação do Monte Vesúvio

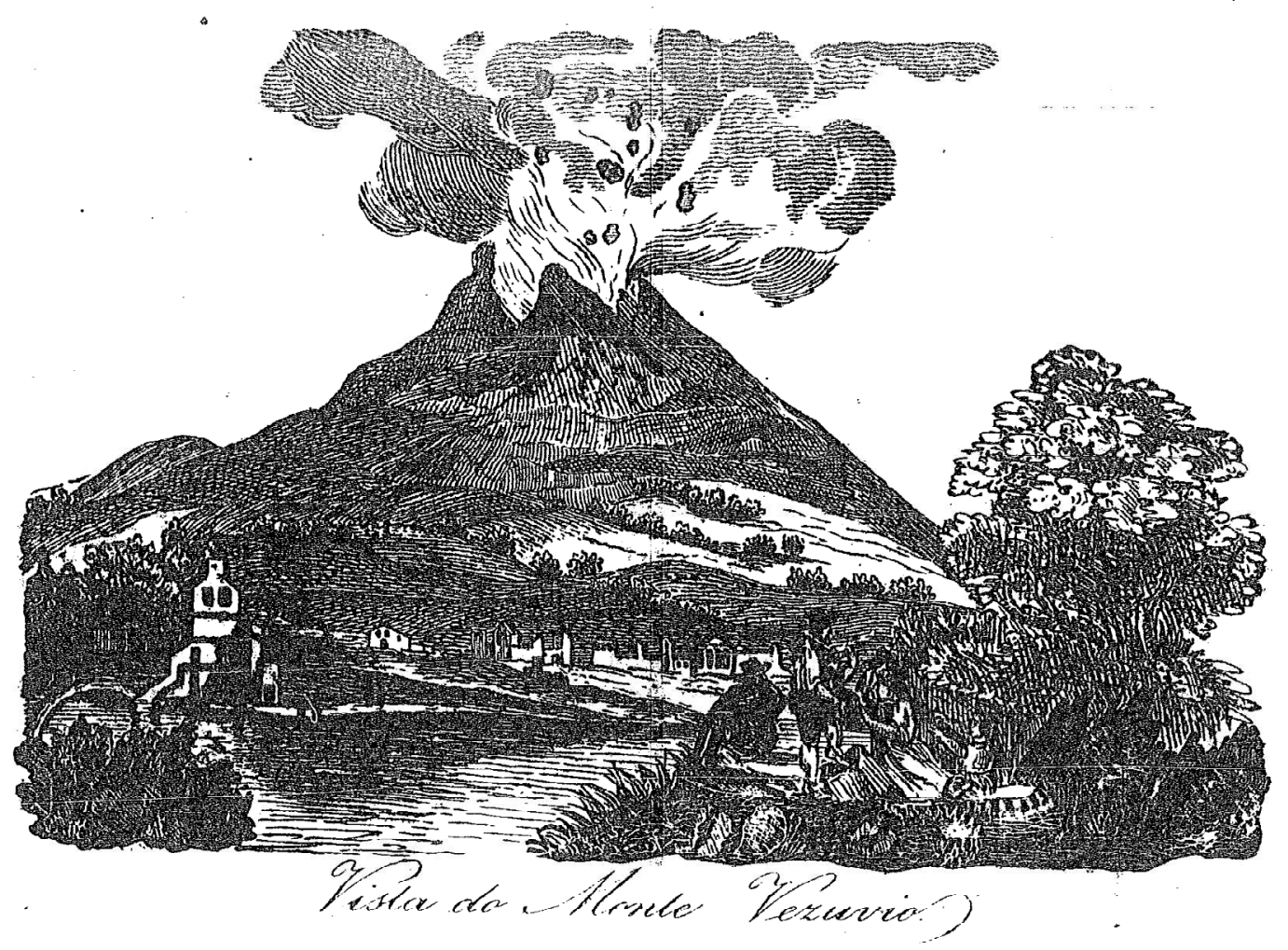

Fonte: A miscelânea scientifica. Rio de Janeiro: Garcia Gimenez, n.3, p. 7, 15 de ago., 1835.

Como podemos perceber, não foram poucas as publicações periódicas dedicadas a vulgarização do conhecimento científico, bem como seus conteúdos foram amplamente variados. Arranhamos nesse artigo uma pequena parte destes tópicos e o uso das imagens nos jornais. Embora efêmeras e com um público leitor não tão amplo, tendo em vista o número de analfabetos existentes no país ao longo de todo séculos XIX, as folhas públicas estavam não apenas alinhadas, mas também atualizadas com os saberes produzidos em outras regiões do mundo. Traduções, teses médicas, tratados de história natural, relatos de viajem e expedições científicas, curiosidades sobre outros lugares do mundo e textos das mais variadas vertentes pautaram a imprensa literária da primeira metade do século XIX do Rio de Janeiro. 
SILVA, Cesar Agenor Fernandes da. Representações, vulgarização e imagética científicas na imprensa da corte fluminense do século XIX. Domínios da Imagem, Londrina, v. 10, n. 19, p. 40-75, jul./dez. 2016.

ISSN 2237-9126

Aos leitores brasileiros, ou no caso específico os habitantes da Corte, que se interessavam por este tipo de conteúdo, nunca lhes faltaram fontes de informação e formas de ampliar suas representações acerca do mundo que os cercava.

\section{Referências}

\section{Fontes primárias}

Periódicos (1808 a 1820)

CORREIO BRAZILIENSE. Londres, 1808-1822.

O Patriota - Jornal Literário, Político e Mercantil \&c.. Rio de Janeiro: Impressão Régia, 1813-1814.

Periódicos (1820 a 1830)

Annaes Fluminense de Sciencias, Artes e Literatura. Rio de Janeiro: Typ. de Santos e Sousa, Tomo 1, n.1, janeiro 1822.

Jornal Scientifico, Economico e Litterario. Rio de Janeiro: Typ. de Torres, v.1, n.1 (22 de maio de 1826)-v.1, n.3 (julho de 1826).

Periódicos (1830 a 1840)

A Gazeta dos Domingos: revista enciclopédica semanal do Rio de Janeiro. Rio de Janeiro: Typ. Americana, v.1, n.1, 1839.

A Miscellania Scientífica. Rio de Janeiro: Tip. de José Andrés Garcia Ximenes, 1835.

A Sciencia: revista synthetica dos conhecimentos humanos. Rio de Janeiro: Typ. de Silva Lima, Anno 1, n.1 (02 de julho de 1847 - 22 de julho de 1848).

A Verdade: jornal miscelanico. Rio de Janeiro: Typ. Nacional, 1832-1834.

Guanabara: revista mensal artistica, scientifica e litteraria. Rio de Janeiro: Typ. Guanabarense, de L.A.F. de Menezes, 1850.

Minerva Brasiliense: jornal de sciencias, lettras e artes. Rio de Janeiro: 
SILVA, Cesar Agenor Fernandes da. Representações, vulgarização e imagética científicas na imprensa da corte fluminense do século XIX. Domínios da Imagem, Londrina, v. 10, n. 19, p. 40-75, jul./dez. 2016.

ISSN 2237-9126

Typ. de J.E.S. Cabral, 1843-1845.

Niterói, revista brasiliense letras e artes. Paris: Dauvin et Fontaine, Libraires, 1836. Disponível em:

<<http://www.brasiliana.usp.br/bbd/handle/1918/6>> Acesso em maio de 2009.

O Auxiliador da Indústria Nacional. Rio de Janeiro: Tip. de SeignotPlanchet, 1833-35; 1838; 1841; 1847-89.

O Beija-Flor: annaes brasileiros de sciencia, politica, litteratura, etc. Rio de Janeiro: Tip. de Gueffier, 1830.

O Globo: jornal philosophico, literario, industrial e scientifico. Rio de Janeiro: Typ. J.R. da Costa, 1844.

O Gosto: jornal de theatros, litteratura, modas, poesia, musica... Rio de Janeiro: Typ. Imparcial de F. de P. Brito, Vol.1, n.1 (05 de agosto de 1843)vol.1 , n.5 (07 de setembro de 1843).

O Indicador da Utilidade Publica. Folha política, scientifica, e litteraria. Rio de Janeiro: Tipografia de Pereira, 1836.

O Propagador de conhecimentos uteis. Rio de Janeiro: Typ. Americana, 1836.

Periódicos (1840 a 1850)

Guanabara: revista mensal artistica, scientifica e litteraria. Rio de Janeiro: Typ. Guanabarense, de L.A.F. de Menezes, 1850.

Minerva Brasiliense: jornal de sciencias, lettras e artes. Rio de Janeiro: Typ. de J.E.S. Cabral, 1843-1845.

Revue francaise: litterature, sciences, beaux arts, politique... Rio de Janeiro: Imprimerie e chal. de C. H. Frirey, Vol.1, n.1 (01 de maio de 1839)-vol.2, n.4 (01 de abril de 1840). 
SILVA, Cesar Agenor Fernandes da. Representações, vulgarização e imagética científicas na imprensa da corte fluminense do século XIX. Domínios da Imagem, Londrina, v. 10, n. 19, p. 40-75, jul./dez. 2016.

ISSN 2237-9126

\section{Referências}

BASILE, Marcelo. Projetos de Brasil e construção nacional na imprensa fluminense (1831-1835). In: NEVES, Maria Bastos P. Neves; MOREL, Marco; FERREIRA, Tânia Maria Bessone da C. (orgs.). História e Imprensa: representações culturais e práticas de poder. Rio de Janeiro: DP\&A, FAPERJ, 2006.

BURKE, Peter. Modernidade, cultura e consumo. In: BUENO, Maria Lucia; CAMARGO, Luis Octávio de Lima. (Org.) SENAC. Cultura e Consumo: estilos de vida na contemporaneidade. São Paulo (SP): Ed. Senac São Paulo, 2008.

CENTENÁRIO da imprensa no Brasil. RIHGB, 2.v., 1908 (edição especial). Parte I - Gênese e Programa da Imprensa periódica brasileira. Parte II Annaes da imprensa periódica no Brazil.

CHARTIER, Roger. Origens Culturais da Revolução Francesa. São Paulo: Unesp, 2009.

FERREIRA, Luis Otávio. Negócio, política, ciência e vice-versa: uma história institucional do jornalismo médico brasileiro entre 1827-1843. Manguinhos, Rio de Janeiro, Fundação Osvaldo Cruz, v.1 1 (suplemento 1), p.93-107, 2004.

GALLO, Ivone. O Brasil e o socialismo no século XX: Fourieristas no Saí. In: VIDAL, Laurent; LUCA, Tânia Regina de (org.) Franceses no Brasil (séculos XIX-XX). São Paulo: UNESP, 2009.

IPANEMA, Marcello de; IPANEMA, Cybelle de. Imprensa Fluminense: ensaios e trajetos. Rio de Janeiro: Instituto de Comunicação Ipanema, 1984.

KURY, Lorelai. Ciência e nação: romantismo e história natural na obra de E. J. da Silva Maia. Manguinhos, Rio de Janeiro, Fiocruz, v.2, p.267-291, jul.-out., 1998.

-Viajantes naturalistas no Brasil oitocentista: experiência, relato e imagem. Manguinhos, v.3 (suplemento), p.863-880, 2001.

LEITE, Renato Lopes. Republicanos e libertários: pensadores radicais no Rio de Janeiro (1822). Rio de Janeiro: Civilização Brasileira, 2000.

LUSTOSA, Isabel. Insultos Impressos: a guerra dos jornalistas na 
SILVA, Cesar Agenor Fernandes da. Representações, vulgarização e imagética científicas na imprensa da corte fluminense do século XIX. Domínios da Imagem, Londrina, v. 10, n. 19, p. 40-75, jul./dez. 2016.

ISSN 2237-9126

independência (1821-1823). São Paulo: Cia das Letras, 2000, 497p.

MARQUESE, Rafael Bivar de. Administração \& Escravidão. Ideias sobre a gestão da agricultura escravista brasileira. São Paulo: HUCITEC, 1999.

. Feitores do corpo, missionários da mente. Senhores, letrados e o controle dos escravos nas Américas, 1660-1860. São Paulo: Cia das Letras, 2004.

MARTINS, Wilson. História da Inteligência brasileira. v.2 (1794-1855). São Paulo: Cultrix; Edusp, 1977-78.

MORAIS, Rubens de Borba. Livros e bibliotecas no Brasil colonial. Rio de Janeiro: Livros Técnicos e Científicos. São Paulo: Secretaria de Cultura, Ciência e Tecnologia do Estado de São Paulo, 1979.

NAXARA, Márcia Regina Capelari. Cientificismo e sensibilidade romântica.Brasília: UNB, 2004.

PALLARES-BURKE, Maria Lucia Garcia. A imprensa periódica como uma empresa educativa no século XIX. Cadernos de Pesquisa, FGV, n.104, p.144-161, jul., 1998.

The Spectator, o teatro das luzes - diálogo e imprensa no século XVIII. São Paulo: HUCITEC, 1995.

SILVA, Wlamir. A imprensa pedagógica liberal na província de Minas Gerais (1825-1842); ambos In: NEVES, Maria Bastos P. Neves; MOREL, Marco; FERREIRA, Tânia Maria Bessone da C. (orgs.). História e Imprensa: representações culturais e práticas de poder. Rio de Janeiro: DP\&A, FAPERJ, 2006.

SIMÕES JUNIOR, Álvaro Santos. Da literatura ao jornalismo: periódicos brasileiros do século XIX. Patrimônio e Memória, Assis, v.n.2, p.1-20, 2006.

SODRÉ, Nelson Werneck. História da Imprensa no Brasil. 2.ed. Rio de Janeiro: Graal, 1977.

VIANNA, Hélio. Contribuição a história da imprensa brasileira (1812-1869). Rio de Janeiro: Imprensa Nacional, 1945.

VOLVELLE, Michel. Imagens e Imaginário na História: fantasmas e certezas nas mentalidades desde a Idade Média até o século XX. São Paulo: Ática, 1991. 